\title{
Health-related quality of life in patients with narcolepsy types 1 and 2 from a Sleep Center in Brazil
}

\author{
Qualidade de vida relacionada à saúde em pacientes com narcolepsia \\ tipos 1 e 2 de um Centro de Sono no Brasil
}

Renata Carvalho CREMASCHI1,2, Camila HIROTSU1,3, Sergio TUFIK', Fernando Morgadinho COELHO',2

\begin{abstract}
Introduction: Narcolepsy patients have higher prevalence of comorbidities, such as obesity, depression, and pain. Narcolepsy symptoms and concomitant medical conditions can impact the daily activities of patients. The objective of this study is to describe the quality of life in a sample of patients with narcolepsy, and the influence of the nutritional status in health domains. Methods: At Unifesp, two groups of 33 patients (narcolepsy types 1 and 2 meeting 2014 criteria, concerning hypocretin-1) and 33 controls without sleepiness, matched by age and sex, filled out the SF-36. Results: Narcolepsy groups, regardless of their nutritional status, had significantly lower scores in all domains, compared to controls, mainly in Role-physical, Role-emotional, and Energy/Fatigue. Role-physical score was lower in type 1 than in type

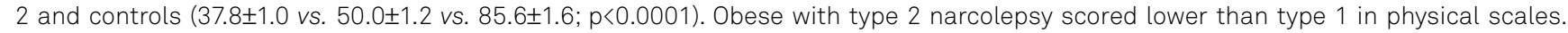
Conclusion: In a Sleep Center in São Paulo, Brazil, physical and mental health were impaired in narcolepsy types 1 and 2. The first report of the poor health status in Brazilians with narcolepsy type 2 suggests that obesity negatively affects physical domains.
\end{abstract}

Keywords: Narcolepsy; Hypocretin-1; Quality of Life; Obesity.

\section{RESUMO}

Introdução: Pacientes com narcolepsia têm maior prevalência de comorbidades, como obesidade, depressão e dor. Sintomas de narcolepsia e condições médicas concomitantes podem afetar as atividades diárias dos pacientes. O objetivo deste estudo é escrever a qualidade de vida em uma amostra de pacientes com narcolepsia e a influência do estado nutricional nos domínios de saúde. Métodos: Na Unifesp, dois grupos de 33 pacientes (narcolepsia tipos 1 e 2 compatível com os critérios de 2014, em relação a hipocretina-1) e 33 controles sem sonolência, pareados por idade e sexo, preencheram o SF-36. Resultados: Os grupos de narcolepsia, independentemente do estado nutricional, apresentaram pontuações significantemente menores em todos os domínios, comparados aos controles, principalmente nos quesitos físico, emocional e energia/fadiga. A pontuação do critério físico foi menor no tipo 1 do que no tipo 2 e nos controles (37,8 $\pm 1,0$ vs. 50,0 $\pm 1,2$

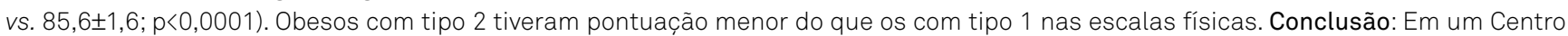
de Sono de São Paulo, Brasil, as saúdes física e mental estavam comprometidas na narcolepsia tipos 1 e 2 . 0 primeiro relato de estado de saúde ruim em brasileiros com narcolepsia tipo 2 sugere que a obesidade afeta negativamente os domínios físicos.

Palavras-chave: Narcolepsia; Orexinas; Qualidade de Vida; Obesidade.

\section{INTRODUCTION}

Narcolepsy is a central disorder of hypersomnolence with chronic daytime sleepiness and abnormal rapid-eye-movement sleep. Cataplexy is a rapid-eye-movement sleep-like state, triggered by positive and strong emotions, which arises in wakefulness. An autoimmune attack of hypothalamic neurons determines deficiency of hypocretin-1 (Hcrt-1) or orexin-A. It causes cataplexy episodes and characterizes patients with narcolepsy type $1^{1}$. Hcrt-1 modulates many neurobiological systems ${ }^{2}$. Indeed, narcolepsy type 2 patients have Hcrt-1 normal levels.

\footnotetext{
${ }^{1}$ Universidade Federal de São Paulo, Departamento de Psicobiologia, São Paulo SP, Brazil.

${ }^{2}$ Universidade Federal de São Paulo, Departamento de Neurologia e Neurocirurgia, São Paulo SP, Brazil.

${ }^{3}$ Lausanne University Hospital, Centre d'investigation et de recherche sur le sommeil, Lausanne, Switzerland.

Renata Carvalho CREMASCHI (D) https://orcid.org/0000-0002-8205-4816; Camila HIROTSU (D) https://orcid.org/0000-0002-6760-0663;

Sergio TUFIK (D) https://orcid.org/0000-0002-4012-4951; Fernando Morgadinho COELHO (D) https://orcid.org/0000-0002-8482-3754

Correspondence: Fernando Morgadinho Coelho; E-mail:fernandomorgadinho@hotmail.com

Conflict of interest: There is no conflict of interest to declare.
}

Received on October 06, 2019; Received in its final form on February 25, 2020; Accepted on March 02, 2020. 
Different tools have been used to investigate the quality of life (QoL) in patients with narcolepsy (clinical aspects, socioeconomic status, and treatment intervention) $)^{6}$. Many studies, using the Medical outcomes study 36-Item Short-Form Health Survey (SF-36), confirm that adult patients with untreated narcolepsy or on psychostimulant medication have significantly decreased QoL. However, neither they evaluated the effect of the type of narcolepsy nor the impact of the disease in Latin American patients.

This study describes health-related QoL in a sample of patients from a Sleep Center in southeastern Brazil, regarding the type of narcolepsy (according to Hcrt-1 levels), compared to healthy controls. Additionally, the impact of the nutritional status was examined by categories of body mass index (BMI) in the scores of the survey.

\section{METHODS}

\section{Sample and ethics}

Adult patients with narcolepsy (33 type 1 and 33 type 2) and 33 controls, matched by age and sex, participated in this study at Universidade Federal de São Paulo, São Paulo, Brazil, from 2015 to 2016. All patients met the 2014 Narcolepsy criteria and were on usual pharmacological treatment ${ }^{7}$.

All controls, recruited among students and employees of the University, had normal Epworth sleepiness scale and Stop-Bang questionnaire scores ${ }^{8,9}$. Each participant had at least middle school level of education, in order to complete the self-administered form. The University's Institutional Ethics Committee approved the protocol and consent forms. All participants provided written informed consent.

\section{Study design}

It was a cross-sectional study that assessed QoL through a self-report questionnaire, during the regular follow-up of the patients in the outpatient clinic $^{10}$. Participants were classified into narcolepsy type 1 (NT1), narcolepsy type 2 (NT2), and control (Ctrl) groups, and according to nutritional status [normal range $\left(\mathrm{BMI}<25.0 \mathrm{~kg} / \mathrm{m}^{2}\right)$, overweight $\left(25 \leq \mathrm{BMI}<30.0 \mathrm{~kg} / \mathrm{m}^{2}\right)$, and obese $\left(\mathrm{BMI} \geq 30.0 \mathrm{~kg} / \mathrm{m}^{2}\right]$.

Hcrt-1 levels were measured by radioimmunoassay at the Center for Narcolepsy in the Department of Psychiatric and Behavior Science at Stanford University, USA ${ }^{11}$. All participants answered the Epworth Sleepiness Scale (ESS) and the Beck Depression Inventory (range 0-63) ${ }^{12}$.

\section{Outcomes - The 36-Item \\ Short-Form Health Survey}

The SF-36 is a multi-purpose tool that measures general health concepts in different populations ${ }^{13}$. The 36 items, organized in an 8-scale profile, were selected from the 40 original components of the Medical Outcomes Study ${ }^{14}$.
The scores range from 0 to 100, with lower scores indicating a worse condition ${ }^{10,15}$.

\section{Statistical analysis}

Data were examined using SPSS software for Windows 8, version 21.0. Pearson's chi-square, parametric and non-parametric analyses were executed for descriptive statistics. The results are presented as means \pm standard deviation and percentages (\%). Models of the Generalized Linear Model (Poisson log-linear regression) analyzed the outcomes, followed by a post-hoc with Bonferroni test. The significant level considered was $\mathrm{p}<0.05$.

\section{RESULTS}

Each group had 27 (68.7\%) women and the mean age in years was $36.2 \pm 10.2$ in Ctrl, $36.3 \pm 9.7$ in NT1 and $35.3 \pm 10.8$ in NT2 $(p=0.91)$. There were no significant differences among the groups in terms of ethnicity, level of education, and occupation. As expected, there was a higher frequency of cataplexy in NT1, compared to NT2 (93.9 vs. 0\%; p<0.0001), but no significant differences in other narcolepsy-related symptoms. NT2 had more history of depression, compared to both Ctrl and NT1 (24.2 vs. 3 vs. 3\%; p=0.004), but did not see any other difference in anxiety, arterial hypertension, diabetes or dyslipidemia.

There were no significant differences between NT1 and NT2 according to the use of psychostimulant or antidepressant drugs. However, NT1 and NT2 used more antidepressants than $\mathrm{Ctrl}$ (48.5 vs. 54.5 vs. 12.1\%; $\mathrm{p}=0.001)$. NT1 had BMI mean score higher than Ctrl and NT2 (30.7 \pm 5.8 vs. 25.5 \pm 4.6 vs. $\left.24.6 \pm 4.2 \mathrm{~kg} / \mathrm{m}^{2} ; \mathrm{p}<0.0001\right)$, such as higher numbers of obese people [19 $(54.5 \%)$ in NT1, 5 (15.2\%) in Ctrl, and 2 $(6.1 \%)$ in NT2; $<<0.0001]$. NT1 and NT2 had higher scores

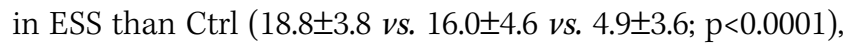
as well as higher Beck Depression Inventory scores (14.6 \pm 0.7 vs. $15.9 \pm 0.7$ vs. $4.5 \pm 0.4$; $\mathrm{p}<0.0001$ ).

NT1 and NT2 had lower SF-36 mean scores than Ctrl in the eight domains of physical and mental health. Role-physical, Role-emotional, and Energy/Fatigue were the most affected. The only domain in which the scores differed between narcolepsy groups was the Role-physical one. NT1 had lower mean score than NT2 (37.8 \pm 1.0 vs. 50.0 $\pm 1.2 ; \mathrm{p}<0.0001)$ (Table 1).

According to nutritional status, NT1 and NT2 had lower mean scores than Ctrl in all physical and mental health scales (Figures 1 and 2). In obese and overweight individuals, NT2 showed lower mean scores than NT1 in physical health scales and Physical functioning, respectively. In the normal range, NT2 Role-physical mean score was higher than NT1 (Figure 1).

In obese people, NT2 Energy/Fatigue and Role-emotional mean scores were lower than NT1. Between overweight NT1 and NT2, the mean scores of SF-36 mental health 
varied according to the domain. In overweight subjects, NT1 Energy/Fatigue, Social functioning, and Mental health mean scores were higher than NT2. In contrast, in overweight individuals, NT1 Role-emotional mean scores were lower than NT2. In normal range, NT2 showed higher

Table 1. Medical outcomes study 36-Item short-form survey among control, narcolepsy type 1 and narcolepsy type 2 groups. Analysis performed by generalized linear model (Poisson regression).

\begin{tabular}{|c|c|c|c|c|}
\hline & $\begin{array}{l}\text { Control } \\
(n=33)\end{array}$ & $\begin{array}{c}\text { Narcolepsy } \\
\text { type } 1 \\
(n=33)\end{array}$ & $\begin{array}{c}\text { Narcolepsy } \\
\text { type } 2 \\
(n=33)\end{array}$ & $p$-value \\
\hline \multicolumn{5}{|c|}{ Physical health scales (0-100) } \\
\hline $\begin{array}{l}\text { Physical } \\
\text { functioning }\end{array}$ & $90.9 \pm 1.6$ & $68.3 \pm 1.4^{\star}$ & $64.2 \pm 1.3^{*}$ & $<0.0001$ \\
\hline Role-physical & $85.6 \pm 1.6$ & $37.8 \pm 1.0 *$ & $50.0 \pm 1.2^{\star \#}$ & $<0.0001$ \\
\hline Bodily pain & $83.4 \pm 1.5$ & $53.5 \pm 1.2^{\star}$ & $53.5 \pm 1.2 *$ & $<0.0001$ \\
\hline General health & $78.4 \pm 1.6$ & $50.0 \pm 1.2^{\star}$ & $52.9 \pm 1.2^{\star}$ & $<0.0001$ \\
\hline \multicolumn{5}{|c|}{ Mental health scales $(0-100)$} \\
\hline Role-emotional & $100 \pm 1.9$ & $31.8 \pm 1.2^{\star}$ & $28.0 \pm 1.0 *$ & $<0.0001$ \\
\hline $\begin{array}{l}\text { Social } \\
\text { functioning }\end{array}$ & $89.2 \pm 1.7$ & $54.7 \pm 1.6^{*}$ & $57.1 \pm 1.6^{*}$ & $<0.0001$ \\
\hline Mental health & $81.4 \pm 1.5$ & $53.5 \pm 1.2^{\star}$ & $52.7 \pm 1.2^{*}$ & $<0.0001$ \\
\hline Energy/Fatigue & $72.7 \pm 1.4$ & $38.6 \pm 1.0 *$ & $38.1 \pm 1.0 *$ & $<0.0001$ \\
\hline
\end{tabular}

* $p<0.05$ compared to the control group; ${ }^{p} p<0.05$ compared to narcolepsy type 1 group.
Energy/Fatigue mean score and lower Role-emotional mean score than NT1 (Figure 2).

\section{DISCUSSION}

Brazilian normative data for SF-36 selected individuals from urban and rural areas of the five regions of the country, which reflects a possible inequality of the population ${ }^{16}$. The mean scores of almost all the domains in Brazil were lower than the compared countries. This study attempted to diminish the heterogeneity among the groups ${ }^{17}$.

In our sample, narcolepsy groups were not different in daytime sleepiness, medications, and depression indicators. Many comorbidities contributed to the poor QoL in narcolepsy, and narcolepsy patients had lower overall scores on all domains when compared to controls. Role-physical, Role-emotional, and Energy/Fatigue were the most affected domains. Our results confirm the negative impact of narcolepsy in QoL, mainly on type 1.

Indeed, psychostimulants improve QoL in narcolepsy patients ${ }^{18,19}$. Only one Japanese study showed disabling QoL in narcolepsy type 2 patients, without significant difference in the domains between the types of narcolepsy in drug-naïve patients ${ }^{20}$.

Perception of QoL in Brazilian adult patients with narcolepsy showed diminishing in psychological, social, and all
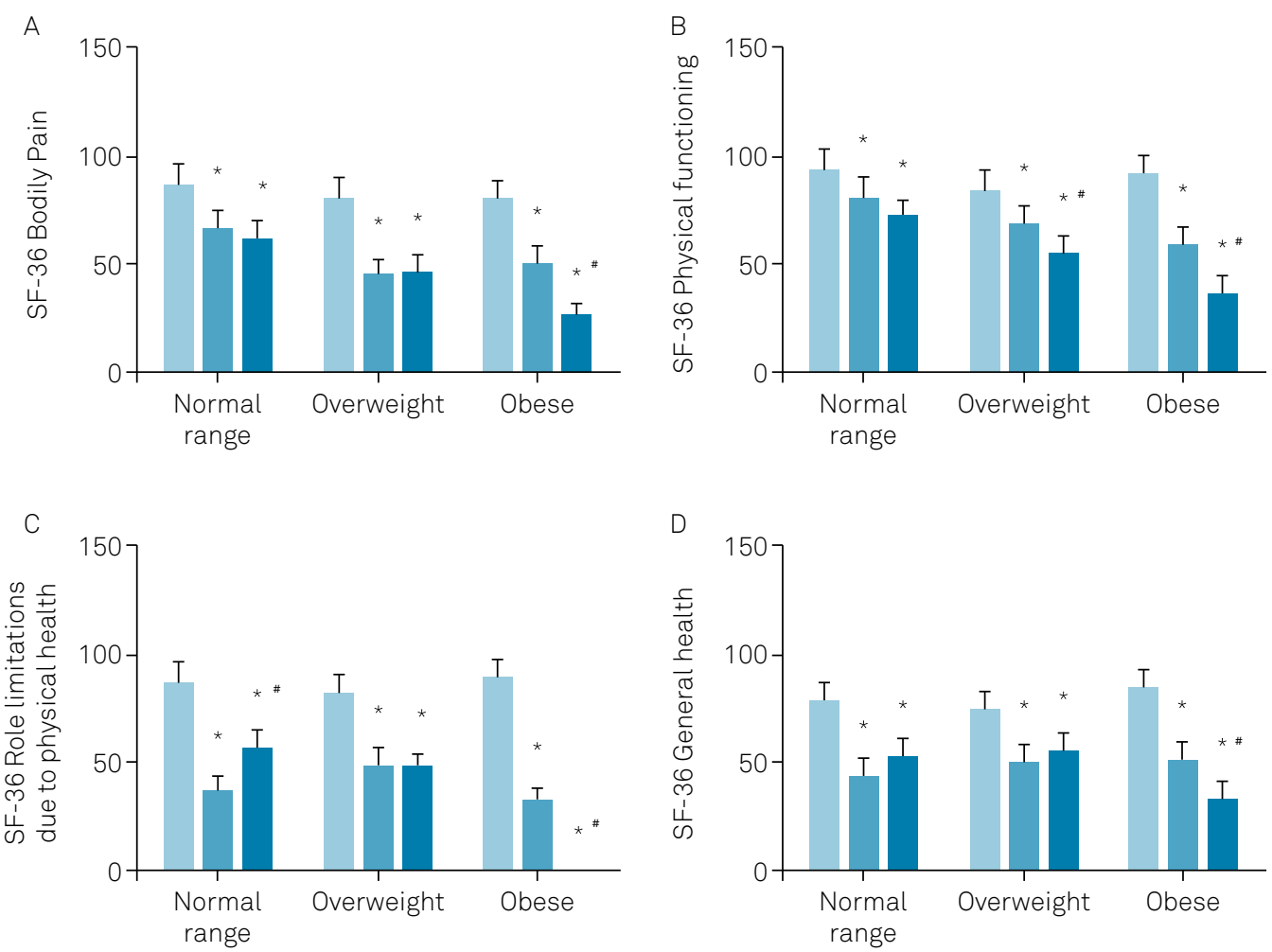

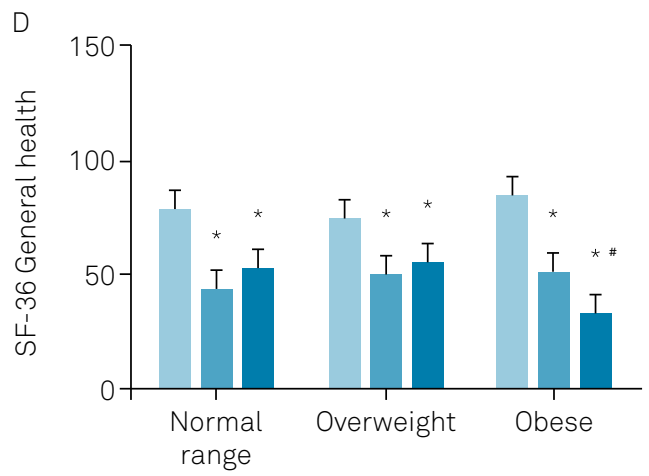

${ }^{*} p<0.05$ compared to the control group; \#p<0.05 compared to the narcolepsy type 1 group.

Figure 1. Health-related quality of life, assessed by 36-Item Short-Form Health Survey (SF-36) physical health scales, according to the nutritional status and the diagnostic group. A: Bodily pain (0-100); B: Physical functioning (0-100); C: Role limitations due to physical health (0-100); D: General health (0-100). Analysis performed by generalized linear model (Poisson regression). 
aspects of physical domains comparing to controls without difference in the social-economic profile ${ }^{21}$.

Overall, the domains affected in narcolepsy groups were similar to those of previous publications, with a higher impact in the physical domain. Patients with narcolepsy in Germany and the United Kingdom had the greatest deficiency in the Role-physical, Energy/Fatigue, and Vitality domains ${ }^{22,23}$. Norwegian patients with narcolepsy type 1 had lower scores than those of the general population, particularly in Bodily pain, Social functioning, and General Health ${ }^{24}$.

The scores of NT1 in QoL, in all domains, were lower than Ctrl, according to SF-36 Brazilian Portuguese version. In contrast to Portuguese patients with narcolepsy, Italian patients with narcolepsy had neither lower scores in Physical functioning nor in Bodily pain than those in national surveys ${ }^{25,26}$. A five-year prospective cohort identified a stable impairment in Italian patients with narcolepsy ${ }^{27}$.

Role-physical NT1 had lower score than NT2, aware of what can be associated to physical aspects, such as obesity. Obese NT2 revealed the lowest scores of physical health, mostly Role-physical. Narcolepsy healthcare programs are suggested to closely target weight control in all patients.

As narcolepsy is a rare disease, the superimposition with the insufficient recognition of the disease in our country restricted patient recruitment ${ }^{28}$. Due to the smaller number of obese in NT2, and the low prevalence of obesity in the literature in this group, the differences in the physical health domain in the narcolepsy groups may represent a statistical influence bias on the type of data distribution ${ }^{29}$. Thus, additional studies are necessary to investigate how obesity influences the scores.

Factors influencing the QoL in our narcolepsy groups may comprise the difficulties to accurately diagnose (delayed suspicion, onset symptoms, mistaken identification) and treat (prompt availability and costs of medicines) narcolepsy. This occurs in various degrees in all populations, largely in our country, which has few centers with electrodiagnostic investigation.

Especially in this sample, narcolepsy groups were not different in sleepiness, medication, depression indicators or detailed functional capacity (Stanford Health Assessment Questionnaire). The elevated prevalence of comorbidity and associated medical conditions in these patients are possible causes to understand our outcomes.

Although there is no specific study on the contribution of physical activity and healthy habits of life to improve the health status of these patients, it is intuitive that these procedures could help them to control obesity, its complications, and comorbidities. However, a future analysis must be carried out on the most radical intervention
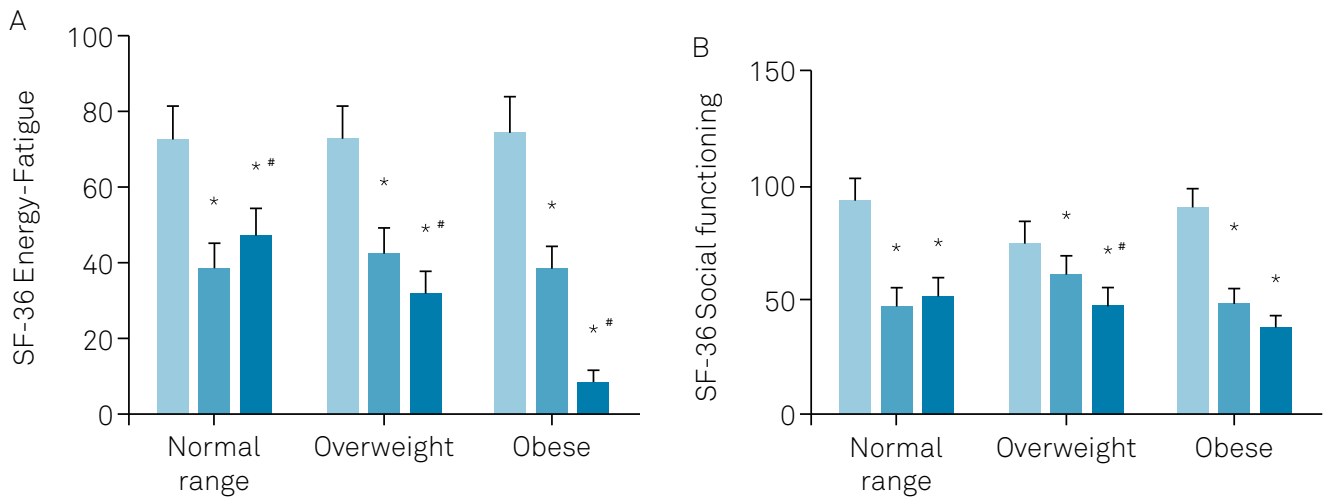

D

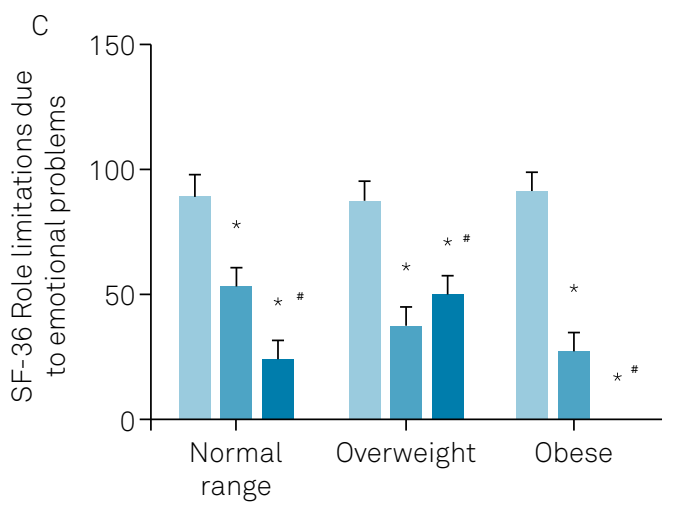

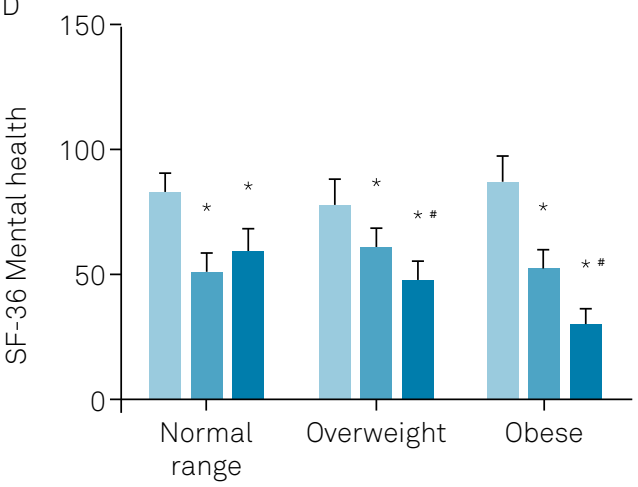

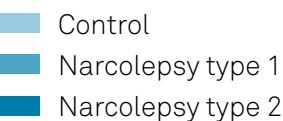

${ }^{*} p<0.05$ compared to the control group; \#p<0.05 compared to the narcolepsy type 1 group.

Figure 2. Health-related quality of life, assessed by 36-Item Short-Form Health Survey (SF-36) mental health scales, according to the nutritional status and the diagnostic group. A: Energy/Fatigue (0-100); B: Social Functioning (0-100); C: Role limitations due to emotional problems (0-100); D: Mental health (0-100). Analysis performed by generalized linear model (Poisson regression). 
to treat obesity in narcolepsy, regardless of a healthy lifestyle routine.

A narcolepsy-specific instrument of QoL for young patients was developed ${ }^{30}$. However, multilingual generic surveys are the main tools to achieve health status. A questionnaire is still crucial to elucidate intrinsic aspects of the types of narcolepsy that reflect the impact of the illness in order to verify the effect of the interventions and the progression of the disease. The correlation between the scales elements with biological markers of disease should be explored.

The QoL of narcolepsy patients seen in a Sleep Center from São Paulo-Brazil was studied. This study confirmed the impairment of QoL according to SF-36 in NT1 and NT2, especially in the domains Role-physical, Role-emotional, and Energy/Fatigue. It is also the first report of the poor health status in narcolepsy patients in Brazil regarding the two different disease forms (NT1 and NT2) and nutritional status.

\section{ACKNOWLEDGMENTS}

The authors are grateful to Associação Fundo de Incentivo à Pesquisa (AFIP) for the financial support, Senne Líquor Diagnóstico and Hospital Israelita Albert Einstein for logistical support with the cerebrospinal fluid samples, and Dr. Ling Lin and Dr. Emanuel Mignot from the Department of Psychiatric and Behavior Science at Stanford University (USA) for the analysis of the Hcrt-1 in the cerebrospinal fluid of the patients with narcolepsy.

\section{References}

1. Liblau RS, Vassalli A, Seifinejad A, Tafti M. Hypocretin (orexin) biology and the pathophysiology of narcolepsy with cataplexy. Lancet Neurol. 2015 Mar;14(3):318-28. https://doi.org/10.1016/S14744422(14)70218-2

2. Li J, Hu Z, de Lecea L. The hypocretins/orexins: integrators of multiple physiological functions. Br J Pharmacol. 2014 Jan;171(2):332-50. https://doi.org/10.1111/bph.12415

3. Cremaschi RC, Hirotsu C, Tufik S, Coelho FM. Chronic pain in narcolepsy type 1 and type 2 - an underestimated reality. J Sleep Res. 2019 Jun;28(3):e12715. https://doi.org/10.1111/jsr.12715

4. Broughton WA, Broughton RJ. Psychosocial impact of narcolepsy. Sleep. 1994 Dec;17(8 Suppl):S45-9. https://doi.org/10.1093/sleep/17. suppl_8.s45

5. Broughton R, Ghanem Q, Hishikawa Y, Sugita Y, Nevsimalova S, Roth B. Life effects of narcolepsy in 180 patients from North America, Asia and Europe compared to matched controls. Can J Neurol Sci. 1981 Nov;8(4):299-304. https://doi.org/10.1017/s0317167100043419

6. Raggi A, Plazzi G, Ferri R. Health-related quality of life in patients with narcolepsy: a review of the literature.J Nerv Ment Dis. 2019 Feb;207(2):84-99. https://doi.org/10.1097/NMD.0000000000000918

7. American Academy of Sleep Medicine. International Classification of Sleep Disorders - Third Ddition (ICSD-3). Darien, IL:American Academy of Sleep Medicine; 2014.

8. Chung F, Yegneswaran B, Liao P, Chung SA, Vairavanathan S, Islam $S$, et al. STOP questionnaire: a tool to screen patients for obstructive sleep apnea. Anesthesiology. 2008 May;108(5):812-21. https://doi. org/10.1097/ALN.0b013e31816d83e4

9. Bertolazi AN, Fagondes SC, Hoff LS, Pedro VD, Menna Barreto SS, Johns MW. Portuguese-language version of the Epworth sleepiness scale: validation for use in Brazil. J Bras Pneumol. 2009;35(9):87783. https://doi.org/10.1590/\$1806-37132009000900009

10. Ciconelli RM, Ferraz MB, Santos W, Meinao I, Quaresma MR. Brazilian-Portuguese version of the SF-36. A reliable and valid quality of life outcome measure. Rev Bras Reumatol. 1999 May/ Jun;39(3):143-50.

11. Mignot E, Lammers GJ, Ripley B, Okun M, Nevsimalova S, Overeem S, et al. The role of cerebrospinal fluid hypocretin measurement in the diagnosis of narcolepsy and other hypersomnias. Arch Neurol. 2002 Oct;59(10):1553-62. https://doi.org/10.1001/archneur.59.10.1553

12. Gorenstein C, Andrade L. Validation of a Portuguese version of the Beck Depression Inventory and the State-Trait Anxiety Inventory in Brazilian subjects. Braz J Med Biol Res. 1996 Apr;29(4):453-7.
13. Gandek B, Ware JE Jr, Aaronson NK, Alonso J, Apolone G, Bjorner $J$, et al. Tests of data quality, scaling assumptions, and reliability of the SF-36 in eleven countries: results from the IQOLA Project. International Quality of Life Assessment. J Clin Epidemiol. 1998 Nov;51(11):1149-58. https://doi.org/10.1016/s08954356(98)00106-1

14. Ware JE Jr., Sherbourne CD. The MOS 36-item short-form health survey (SF-36). I. Conceptual framework and item selection. Med Care. 1992 Jun;30(6):473-83.

15. Martinez TY, Pereira CA, dos Santos ML, Ciconelli RM, Guimarães SM, Martinez JA. Evaluation of the short-form 36-item questionnaire to measure health-related quality of life in patients with idiopathic pulmonary fibrosis. Chest. 2000 Jun;117(6):1627-32. https://doi. org/10.1378/chest.117.6.1627

16. Laguardia J, Campos MR, Travassos C, Najar AL, Anjos LA, Vasconcellos MM. Brazilian normative data for the Short Form 36 questionnaire, version 2. Rev Bras Epidemiol. 2013 Dec;16(4):889-97. https://doi.org/10.1590/s1415-790×2013000400009

17. Laguardia J, Campos MR, Travassos CM, Najar AL, Anjos LA, Vasconcellos MM. Psychometric evaluation of the SF-36 (v.2) questionnaire in a probability sample of Brazilian households: results of the survey Pesquisa Dimensoes Sociais das Desigualdades (PDSD), Brazil, 2008. Health Qual Life Outcomes. 2011 Aug;9:61. https://doi.org/10.1186/1477-7525-9-61

18. Beusterien KM, Rogers AE, Walsleben JA, Emsellem HA, Reblando $J A$, Wang L, et al. Health-related quality of life effects of modafinil for treatment of narcolepsy. Sleep. 1999 Sep;22(6):757-65. https://doi. org/10.1093/sleep/22.6.757

19. Bogan R, Swick T, Mamelak M, Kovacevic-Ristanovic R, Lai C, BlackJ, et al. Evaluation of quality of life in patients with narcolepsy treated with sodium oxybate: use of the 36-Item Short-Form Health Survey in a clinical trial. Neurol Ther. 2016 Dec;5(2):203-13. https://doi. org/10.1007/s40120-016-0053-5

20. Ozaki A, Inoue Y, Nakajima T, Hayashida K, Honda M, Komada Y, et al. Health-related quality of life among drug-naive patients with narcolepsy with cataplexy, narcolepsy without cataplexy, and idiopathic hypersomnia without long sleep time.J Clin Sleep Med. 2008 Dec;4(6):572-8.

21. Rovere H, Rossini S, Reimao R. Quality of life in patients with narcolepsy: a WHOQOL-bref study. Arq Neuropsiquiatr. 2008;66(2a):163-7. https://doi.org/10.1590/S0004282X2008000200004 
22. Dodel R, Peter H, Spottke A, Noelker C, Althaus A, Siebert U, et al. Health-related quality of life in patients with narcolepsy. Sleep Med. 2007 Nov;8(7-8):733-41. https://doi.org/10.1016/j.sleep.2006.10.010

23. Daniels E, King MA, Smith IE, Shneerson JM. Health-related quality of life in narcolepsy. J Sleep Res. 2001 Mar;10(1):75-81. https://doi. org/10.1046/j.1365-2869.2001.00234.x

24. Ervik S, Abdelnoor M, Heier MS, Ramberg M, Strand G. Health-related quality of life in narcolepsy. Acta Neurol Scand. 2006 Sep;114(3):198204. https://doi.org/10.1111/j.1600-0404.2006.00594.x

25. David A, Constantino F, dos Santos JM, Paiva T. Health-related quality of life in Portuguese patients with narcolepsy. Sleep Med. 2012 Mar;13(3):273-7. https://doi.org/10.1016/j.sleep.2011.06.021

26. Vignatelli L, D’Alessandro R, Mosconi P, Ferini-Strambi L, Guidolin $L$, De Vincentiis A, et al. Health-related quality of life in Italian patients with narcolepsy: the SF-36 health survey. Sleep Med. 2004 Sep;5(5):467-75. https://doi.org/10.1016/j.sleep.2004.04.003
27. Vignatelli L, Plazzi G, Peschechera F, Delaj L, D’Alessandro R. A 5-year prospective cohort study on health-related quality of life in patients with narcolepsy. Sleep Med. 2011 Jan;12(1):19-23. https://doi. org/10.1016/j.sleep.2010.07.008

28. Longstreth WT Jr, Koepsell TD, Ton TG, Hendrickson AF, van Belle G. The epidemiology of narcolepsy. Sleep. 2007 Jan;30(1):13-26. https:// doi.org/10.1093/sleep/30.1.13

29. Sonka K, Kemlink D, Busková J, Pretl M, Srůtková Z, Maurovich Horvat E, et al. Obesity accompanies narcolepsy with cataplexy but not narcolepsy without cataplexy. Neuro Endocrinol Lett. 2010;31(5):631-4

30. Chaplin JE, Szakacs A, Hallbook T, Darin N. The development of a health-related quality-of-life instrument for young people with narcolepsy: NARQoL-21. Health Qual Life Outcomes. 2017 Jul;15(1):135. https://doi.org/10.1186/s12955-017-0707-8 